\title{
PENGARUH PENGABUTAN BAHAN BAKAR TERHADAP KUALITAS PEMBAKARAN PADA MESIN INDUK DI MT. BAUHINIA
}

\author{
Ahmad Puji Nugroho ${ }^{a}$, Darjono $^{b}$ dan Okvita Wahyunic \\ ${ }^{a}$ Taruna (NIT.50134954.T) Program Studi Teknika PIP Semarang \\ ${ }^{\mathrm{b}}$ Dosen Program Studi Teknika PIP Semarang \\ ${ }^{\mathrm{c}}$ Dosen Program Studi KALK PIP Semarang
}

\begin{abstract}
ABSTRAK
Dalam sebuah permesinan kapal Injector merupakan alat untuk pengabutan yang berfungsi sebagai penunjang kelancaran sistem pembakaran. Apabila pada akhir penyemprotan Injector bahan bakar menetes atau mengalami kebocoran maka akan terjadi pengabutan kurang sempurna pada saat kapal berlayar. Dalam penelitian ini penulis ingin mengetahui factor, dampak dan upaya yang dilakukan agar pembakaran bahan bakar menjadi sempurna.

Dalam penelitian ini, penulis menggunakan metode kualitatif deskriptif, penulis membatasi faktor-faktor yang dapat mempengaruhi terjadinya gangguan kerja dari sistem pengabutan. Adapun penulis merumuskan masalah yang berdasarkan hasil wawancara yaitu: tersumbatnya lubang nozzle karena adanya kotoran, yang mengakibatkan sistem pengabutan tidak dapat berfungsi secara optimal, sehingga perlunya upaya perawatan yang dilakukan untuk menjaga agar pembakaran mesin induk dapat bekerja secara optimal.

Hasil tersebut dapat diambil kesimpulan yang dapat dijadikan sebagai pedoman untuk melakukan adanya perawatan yang rutin dan terencana dengan baik agar proses pembakaran bahan bakar dapat sempurna.
\end{abstract}

Kata kunci : pengabutan, motor induk, pembakaran

\section{PENDAHULUAN}

\section{A. Latar belakang}

Salah satu komponen yang terdapat pada motor induk khususnya mesin penggerak utama adalah Injector, bahan bakar yang merupakan alat untuk mengabutkan dan menyemprotkan bahan bakar ke dalam silinder yang merupakan suatu sistem yang berfungsi sebagai penunjang kelancaran sistem pembakaran yang ada dalam mesin induk.

Di kapal MT. Bauhinia menggunakan pesawat penggerak utama motor Diesel dua tak merk MAKITA-MITSUI MAN B\&W, yang harus dirawat dengan baik agar penggerak utama bekerja dengan normal. Untuk kelancaran pengoperasian kapal perlu adanya perawatan yang baik terutama pada bagian motor induk yaitu Injector, apabila pada akhir penyemprotan Injector bahan bakar menetes atau mengalami kebocoran maka akan terjadi pengabutan kurang sempurna pada saat kapal berlayar. Sehingga penulis mengambil judul penelitian pengaruh pengabutan bahan bakar terhadap kualitas pembakaran pada mesin induk dengan analisa SWOT.

B. Perumusan masalah

Dalam menganalisa sebuah permasalahan sistem pengabutan bahan bakar dapat kita lakukan secara rutin dengan melihat panduan di manual book dan untuk lebih memudahkan dalam penyusunan penelitian ini, perlu dirumuskan terlebih dahulu 
Ahmad Puji Nugroho, Darjono dan Okvita Wahyuni

masalah-masalah apa saja yang akan dibahas. Ada beberapa masalah yang memerlukan solusi pemecahan masalah, antara lain:

1. Faktor-faktor apa saja yang menyebabkan kualitas pengabutan bahan bakar pada mesin induk tidak optimal?

2. Bagaimana merawat sistem pengabutan bahan bakar agar selalu bekerja secara baik guna mencapai kerja mesin yang optimal?

C. Pembatasan masalah

Pembakaran yang kurang sempurna akibat dari berbagai sistem yang diketahui sistem pengabutan yang kurang maksimal. Maka perlu kiranya bagi penulis untuk membatasi masalah yang akan dibahas. Dalam mengidentifikasi pembahasan masalah tersebut penulis akan membatasi pada sistem pengabutan bahan bakar. Pembahasan itu sesuai dengan pengalaman pada waktu melaksanakan praktek laut di MT. Bauhinia.

D. Tujuan penelitian

1. Untuk mengetahui penyebab tidak optimalnya sistem pengabutan dalam menunjang proses pembakaran pada mesin induk untuk kelancaran pengoperasian kapal dan untuk mengenalkan praktek kerja di kapal bagi taruna agar dapat melakukan identifikasi pengaruh sistem pengabutan terhadap proses pembakaran.

2. Untuk mengetahui cara perawatan pada sistem pengabutan agar selalu berfungsi dengan baik guna mencapai pembakaran mesin induk yang optimal.

E. Manfaat penelitian

Dengan adanya penelitian ini, masalah yang terjadi akan mendapatkan jawaban dan pemecahannya sehingga dapat memberikan tambahan wawasan yang sangat berguna bagi para pembaca. Manfaat yang ingin dicapai penulis dalam penelitian ini antara lain:

1. Manfaat secara teoritis

a. Bertujuan agar dapat mengetahui faktor-faktor apa saja yang dapat mempengarui terjadinya gangguan dalam sistem pengabutan bahan bakar terhadap pembakaran yang sempurna pada mesin induk, bertujuan untuk dapat memperlancar operasional kapal tersebut.

b. Dapat mengetahui apa saja dampak yang ditimbulkan dari gangguan sistem system pengabutan yang kurang optimal dalam pengoperasiannya.

c. Mengetahui upaya yang dilakukan dari dampak yang ditimbulkan.

2. Manfaat secara praktis

Diharapkan bagi para pembaca khususnya taruna-taruni Politeknik Ilmu Pelayaran Semarang maupan instansi-instansi lain semoga setelah membaca penelitian ini dapat memahami bagaimana cara untuk mengatasi gangguan yang terjadi pada sistem pengabutan bahan bakar dan dampak yang ditimbulkan secara langsung dan tidak langsung di atas kapal.

\section{LANDASAN TEORI}

A. Tinjauan Pustaka

1. Sistem pengabutan

a. Pengertian

Menurut para ahli system pengabutan yaitu system dimana cairan yang ditekan sehingga mempunyaidaya pemampatan untuk menekan dan menghasilkan butiran-butiran kecil yang berbentuk kabut sehingga memudahkan untuk mendapatkan titik nyala apinya.

Untuk mendapatkan hasil kerja yang maksimal pada permesinan di 
atas kapal, diperlukan sistem pembakaran yang baik untuk memperoleh kekuatan mesin yang maksimal. (Penyusun Motor Diesel Penggerak Utama, PIP semarang, 2005).

b. Syarat pada sistem injeksi

Sebagai sesuah sistem yang penting sistem injeksi mempunyai persyaratan sebagai berikut, yaitu:

1) Penakaran

Penakaran yang teliti dari bahan bakar berarti bahwa banyaknya bahan bakar yang diberikan untuk tiap silinder harus dalam kesesuaian dengan beban mesin dan jumlah yang tepat sama dari bahan bakar yang harus diberikan kepada tiap silinder untuk setiap langkah daya mesin.

2) Pengaturan waktu

Pengaturan waktu yang layak berarti mengawali injeksi bahan bakar pada saat diperlukan adalah mutlak untuk mendapatkan daya maksimum dari bahan bakar dengan baik serta pembakaran yang sempurna. Kalau bahan bakar diinjeksikan terlalu awal dalam dapur, maka penyalaan akan diperlambat karena suhu udara pada titik ini tidak cukup tinggi. Keterlambatan yang berlebihan akan memberikan operasi yang kasar dan berisik dari mesin serta memungkinkan kerugian bahan bakar karena pembasahan dinding silinder. Akibatnya adalah boros bahan bakar dan asap gas buang hitam dan tidak akan membangkitkan daya maksimum.

3) Kecepatan injeksi bahan bakar

Berarti banyaknya bahan bakar yang diinjeksikan ke dalam ruang bakar dalam satu satuan waktu dalam satu derajat dari perjalanan engkol, kalau dikehendaki untuk menurunkan kecepatan injeksi harus digunakan ujung nozzle dengan lubang yang lebih kecil, untuk menaikkan jangka waktu injeksi bahan bakar.

4) Pengabutan

Bahan bakar menjadi semprotan mirip kabut, tetapi harus disesuaikan dengan jenis ruang bakar. Pengabutan yang baik akan mempermudah pengawalan pembakaran dan menjamin bahwa setiap butiran kecil dari bahan bakar dikelilingi oleh partikel oksigen yang dapat bercampur.

2. Jenis injeksi bahan bakar

a. Injeksi udara

Injeksi udara digunakan pada awal-awal terbentuknya mesin diesel. Saat ini jarang digunakan dan hanya untuk mesin besar yang beroperasi pada bahan bakar yang sangat kental, dalam mesin injeksi udara energi potensial dari udara tekan diubah menjadi energi kinetik, dari energi yang memuai ini digunakan untuk menghantar bahan bakar ke dalam silinder dari katup semprot, untuk mengabutkan bahan bakar, dan untuk menimbulkan pusaran dalam ruang bakar agar bahan bakar dan udara bercampur dengan baik.

b. Injeksi tanpa udara

Injeksi tanpa udara juga dikenal dengan nama injeksi mekanis. Pengabutan injeksi mekanis diperoleh bahan bakar cair dengan tekanan tinggi melewati satu atau beberapa lubang yang masuk ke arus bahan bakar membangkitkan kecepatan tinggi dan ini menimbulkan gesekan besar antara arus cairan dan udara dalam ruang bakar. Karena gesekan ini maka butiran halus 
Ahmad Puji Nugroho, Darjono dan Okvita Wahyuni

muncul dan dipisahkan menjadi butiran sangat kecil.

Metode penyemprotan bahan bakar dan pembentukan campuran ada dua sistem utama yaitu sistem penyemprotan tidak langsung dan sistem penyemprotan langsung. Pada kapal tempat penulis mengadakan penelitian menggunakan sistem penyemprotan langsung. Sistem penyemprotan langsung diterapkan pada seluruh motor putaran rendah dan putaran menegah serta pada sebagian besar dari motor putaran tinggi.

1. Penyemprotan tidak langsung.

Dalam hal ini bahan bakar disemprotkan ke dalam sebuah pembakaran pendahuluan yang terpisah dari ruang pembakaran utama. Ruang tersebut memiliki $25-60 \%$ dari volume total ruang pembakaran. Pada sistem penyemprotan ruang pendahuluan bahan bakar disemprotkan ke dalam ruang tersebut melalui sebuah pengabut berlubang tunggal (pengabut tap) dengan penyemprotan relatif rendah 100 bar. Pengabutan pada tekanan tersebut kurang baik, akan tetapi bahan bakar dapat menyala dengan cepat dengan suhu tinggi dinding ruang pendahuluan tersebut.

2. Penyemprotan langsung

Bahan bakar dengan tekanan tinggi disemprotkan ke dalam ruang pembakaran yang tidak dibagi, tergantung dari pembuatan ruang pembakaran maka untuk keperluan tersebut digunakan sebuah hingga tiga buah pengabut berlubang banyak.

Bahan bakar dengan bantuan pompa bahan bakar tekanan tinggi dipompakan pada saat tepat ke katub bahan bakar yang dilengkapi dengan pengabut, pada waktu dimulai dengan langkah tekan maka bahan bakar mula-mula akan dikompresikan dalam silinder, pompa dan saluran penghubung antara pompa dan pengabut sehinga mencapai tekanan penyemprotan yang disyaratkan dan baru kemudian akan berlangsung penyemprotan dan pengabutan. Antara saat awal langkah tekan dan saat awal penyemprotan terdapat suatu periode perlambatan yang tersebut tergantung dari kontruksi pompa dan volume bahan bakar dalam pompa saluran bahan bakar. Setelah butiran bahan bakar pertama dalam silinder akan terjadi proses kimia dari penyalaan dan pembakaran. Menurut MALEEV, dalam bukunya "Operasi dan Pemeliharaan Mesin Diesel", terdapat dua injeksi bahan bakar.

\section{METODE PENELITIAN}

A. Kerangka pikir penelitian

Berdasarkan wacana di atas, dapat dicari suatu pemecahan masalah dan seharusnya dapat dikurangi bahkan dicegah dengan diterapkannya beberapa strategi perawatan yang tepat sehingga pengoperasian kapal tidak terganggu. Perawatan yang menyangkut perhatian, pegawasan, pemeliharaan, perbaikan, dan faktor sumber daya manusia sebagai operator pelaksana dalam menciptakan kondisi siap operasi dari suatu mesin induk kapal yang pada prinsipnya memerlukan pananganan dan perawatan yang efektif, maka diharapkan dapat menunjang operasional pelayaran yang telah direncanakan oleh perusahan 
pelayaran, sehingga penulis menguraikan cara mengalirkan jalan pemikiran melalui diagram alir atau kerangka pikir sebagai berikut:

Bagan alir dari kerangka pikir penelitian di bawah ini :

Pengaruh perawatan pada injector terhadap kesempurnaan pembakaran pada motor induk di MT. BAUHINIA dengan analisa SWOT.

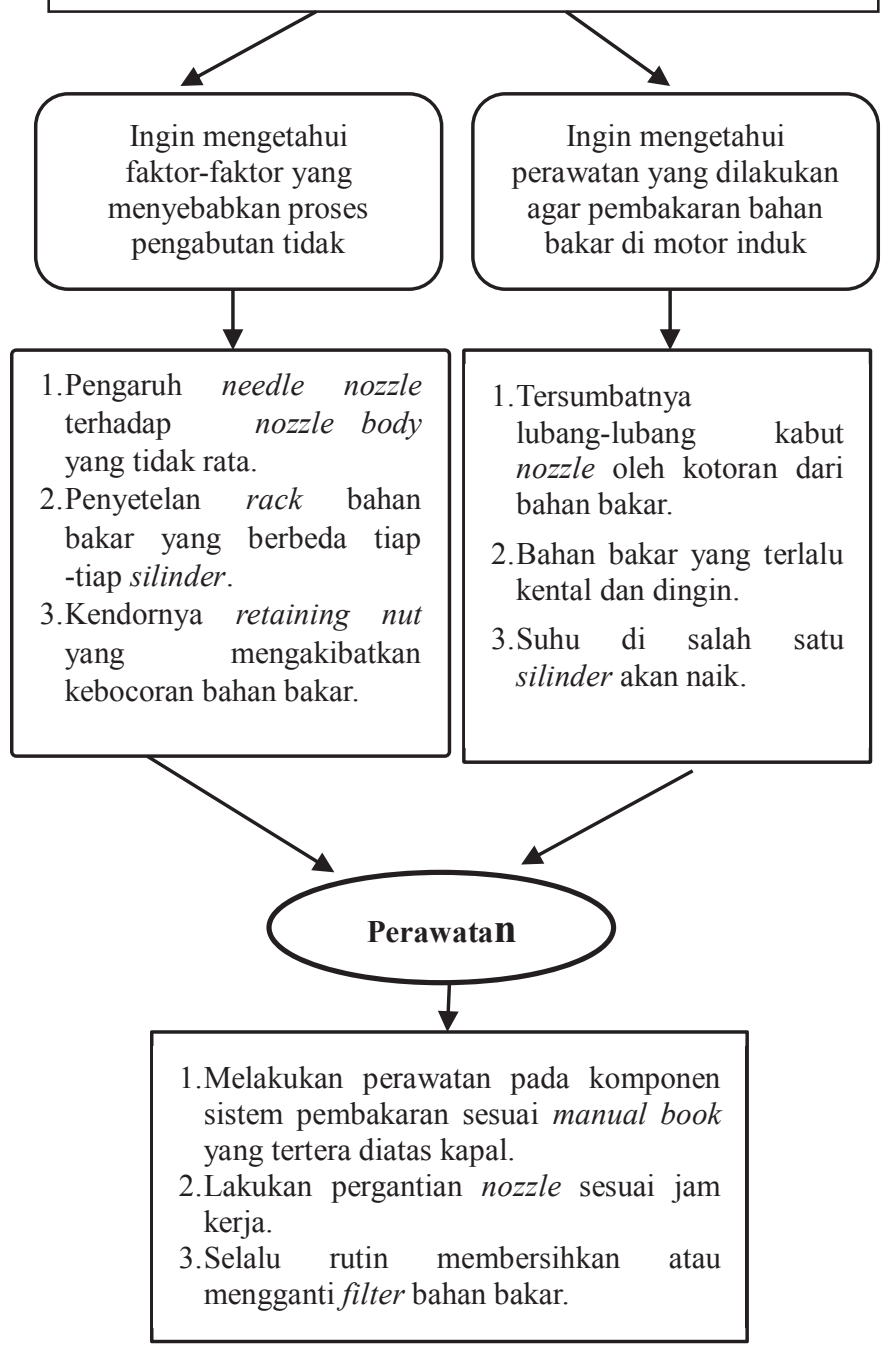

Dalam bagan kerangka pikir di atas menjelaskan bahwa kejadian yang terjadi pada sistem pengabutan mengalami gangguan sehingga harus diadakan identifikasi terhadap suatu masalah yang terjadi. Mengingat peranan system pengabutan yang sangat penting terhadap system pembakaran mesin induk, untuk memudahkan dalam menentukan kemungkinan-kemungkinan dan menentukan konsekuensi-konsekuensi dari resiko bahaya tersebut dari semua kemungkinan yang terjadi tergantung dari seberapa sering hal itu terjadi dan seberapa buruk hal tersebut ketika itu terjadi.

Tahap selanjutnya adalah tahap dimana harus menganalisa dan mempertimbangkan resiko bahaya dari kerja sistem pengabutan, dan menentukan tidakan atau upaya yang dilakukan untuk perawatan dan perbaikan.

B. Waktu dan tempat penelitian

Pada penulisan penelitian ini dilakukan pengkajian dengan menggunakan fakta-fakta dari pengalaman juga pengetahuan yang telah dipadukan dari permasalahan yang penulis lihat dan alami saat melaksanakan praktek berlayar di MT. Bauhinia selama kurang lebih 12 bulan 14 hari yang terhitung dari 03 September 2015 sampai dengan 17 September 2016.

C. Sumber data

1. Data primer

"Data primer merupakan sumber-sumber dasar yang merupakan bukti atau saksi utama dari kejadian yang lalu, dimana sumber primer adalah tempat atau gudang penyimpanan yang orisinal dari data sejarah". Dimana data tersebut diperoleh dari hasil pengamatan langsung, yang diperoleh dengan cara metode survey yaitu dengan mengamati, mengukur dan mencatat serta hasil berdiskusi dengan masinis yang terkait secara langsung di lokasi penelitian Moh. Nasir (2005:50).

2. Data sekunder

Data sekunder merupakan data pelengkap dari data primer yang didapat dari sumber dokumentasi, arsip resmi yang dikumpulkan penulis selain dari sumber terkait data ini dapat dijadikan acuan dan diperoleh 
Ahmad Puji Nugroho, Darjono dan Okvita Wahyuni

dari perpustakaan seperti literatur, bahan kuliah dan data dari perusahaan serta hal-hal lainnya yang berhubungan dengan penelitian ini. Data tersebut dijadikan pembanding dan sumber untuk memperkuat jawaban dalam pemecahan masalah. "Data sekunder merupakan sumber yang tidak langsung memberikan data kepada pengumpul data,misalnya melalui orang lain atau melalui dokumen." Sugiyono (2009:225)

Dari apa yang penulis peroleh sesuai langkah di atas, maka penulis dapat menyimpulkan data yang berkaitan dengan penelitian yang dilakukan. Data yang diperoleh diolah sesuai dengan teori dan metode yang telah ditetapkan dari awal sebelum penulis melakukan pengumpulan data.

Setelah semua dianggap selesai maka kita boleh menarik sebuah kesimpulan apa yang telah dianalisa dan dibahas. Kemudian memberikan saran yang sesuai dengan apa yang sudah disimpulkan dengan saran yang diberikan dapat sebagai bahan masukan dalam meningkatkan kinerja kerja mesin induk, barulah langkah-langkah dianggap selesai.

D. Metode pengumpulan data

Data dan informasi yang diperlukan untuk penulisan penelitian ini dikumpulkan melalui:

1. Metode observasi, yaitu mengadakan pengumpulan data yang dilakukan melalui pengamatan secara langsung dengan disertai pencatatan terhadap keadaan atau perilaku obyek sasaran pada sistem pengabutan di lapangan dimana Penulis melaksanakan praktek laut di kapal MT. Bauhinia.

2. Metode kepustakaan (Library Research), yaitu penelitian yang dilakukan dengan cara membaca dan mempelajari literatur, buku-buku dan tulisan yang berhubungan dengan masalah yang dibahas untuk memperoleh landasan teori yang akan digunakan dalam pembahasan nantinya.

3. Metode wawancara, yaitu suatu cara pengumpulan data yang digunakan untuk memperoleh informasi langsung dari sumber-sumbernya. Wawancara merupakan proses tanya jawab secara lisan yang dilakukan seseorang saling berhadapan dan saling menerima serta memberikan informasi. Wawancara sebagai alat pengumpul data menghendaki adanya komunikasi langsung antara penulis dengan sasaran penelitian antara masinis dan anak buah kapal MT. Bauhinia. Wawancara adalah metode pokok dalam teknik pengumpulan data.

\section{E. Langkah analisa data}

Langkah-langkah yang dilakukan setelah memulai langkah untuk menganalisa yaitu mengadakan penelitian di MT. Bauhinia untuk mengetahui situasi dengan bekal pengetahuan dari apa yang didapatkan dari studi kepustakaan. Selanjutnya kita harus memulai identifikasi-identifikasi masalah yang kita temui, maka kita dapat menemukan metode penelitian yang sesuai.

Data yang diperoleh diolah sesuai dengan teori dan metode yang telah kita tetapkan dari awal sebelum kita melakukan pengumpulan data. Data yang telah diolah kemudian dianalisa sebagai hasil yang diperoleh dibandingkan dengan hasil-hasil dan disimpulkan teori yang kita gunakan.

Setelah semua dianggap selesai, maka kita boleh menarik sebuah kesimpulan apa yang telah dianalisa dan dibahas. Kemudian juga memberikan saran yang sesuai dengan kita simpulkan, Dan ini dapat merupakan bahan masukan dalam meningkatkan kinerja kerja mesin induk, barulah langkah-langkah dianggap 
selesai.

\section{HASIL PENELITIAN DAN PEMBAHASAN}

A. Gambaran umum obyek yang diteliti Dalam bab ini penulis menggambarkan secara umum mengenai objek yang diteliti yaitu Injector, adalah suatu alat yang digunakan untuk mengabutkan bahan bakar ke dalam silinder pada saat yang tepat yaitu pada akhir langkah kompresi. Mengingat pentingnya fungsi injector tersebut maka injector dibuat dengan bahan-bahan yang sudah diuji dengan perhitungan yang akurat mengutamakan efisiensi serta keamanan.dalam spesifikasi mesin induk di kapal taruna praktek yaitu sebagai berikut:

Nama kapal : MT. BAUHINIA

Nama perusahaan : BERLIAN LAJU TANKER Ltd.

Tipe kapal : OIL \& CHEMICAL TANKER

Flag : HONGKONG

Call sign : VRPP2

IMO number : 9153575

Classfication : NKC

Main engine

Maker

: MAKITA CORPERATION

Type : MAKITA MITSUI MAN B \& W / 6L 35MC

Max. Output : 5280 ps at. $210 \mathrm{rpm}$

DWT : $6118 \mathrm{M}^{3}$

Dengan demikian injector dapat beroperasi dengan kemampuan yang baik dan dapat diandalkan dalam jangka waktu yang sudah ditentukan yang didasarkan pengujian pada saat pembuatan oleh pembuat dari mesin tersebut (maker). Suatu alat akan mengalami perubahan bentuk (meleleh) bahan setelah sekian lama digunakan apalagi sampai melampaui dari jam kerja yang telah ditentukan oleh maker, jika masih terus digunakan maka alat tersebut tidak akan bekerja dengan baik begitu juga dengan injector.

Untuk mengetahui ada tidaknya gangguan pada pengabutan dapat dilakukan dengan pengambilan diagram indikator.

Cara pengambilan diagram indikator dilakukan dengan bantuan beberapa klem dan sebuah kertas berbentuk persegi panjang dan diklem pada tromol. Bila pencatat ditekankan pada kertas akan tergores sebuah garis tipis yang akan membentuk suatu diagram.

Namun sebelum pengambilan diagram indikator ada beberapa persyaratan yaitu :

1. Putaran harus mencapai full speed ahead;

2. Tekanan dan suhu harus sudah bekerja normal;

3. Kapal harus steady sea goes;

4. Kapal harus even keel;

5. Kapal sarat dengan muatan (full loaded).

Setelah syarat tersebut diatas dipenuhi maka dapat dilakukan pengambilan diagram indikator.

Cara pengambilan diagram indikator adalah sebagai berikut :

1. Katup indikator pada silinder yang diperiksa dibuka sebentar sehinggga gas yang keluar membersihkan katup dan jelaga kemudian ditutup kembali.

2. Alat indikator ditempatkan pada katup dengan cara mengikat alat pengambilan diagram indikator tersebut dengan katup silinder indikator, pada tromol ditempatkan kertas diagram. Tali tromol diikatkan pada mesin penggerak.

3. Dengan bantuan katup silinder indikator dihubungkan dengan udara luar dan pencatat ditekankan pada kertas indikator. Pada kertas tersebut digariskan garis atmosfer.

4. Katup ditempatkan pada suatu kedudukan tertentu sehinggga silinder indikator berhubungan dengan silinder motor, dan selama sebuah 
Ahmad Puji Nugroho, Darjono dan Okvita Wahyuni

proses kerja pencatat ditekankan pada kertas indikator. Dengan demikian telah tertulis diagram indikator.

5. Agar lintasan tekanan di dalam silinder dapat dinilai lebih baik, selama perubahan tekanan, maka dipergunakan pegas yang lembek pada alat indikator. Pada perubahan tekanan kecil dapat diperoleh simpangan tegak yang besar dengan pencatatnya.

Pembahasan yang akan dilakukan adalah melalui identifikasi metode SWOT dengan melihat faktor-faktor dari kekuatan (Strengths), kelemahan (Weakness), kesempatan (Opportunities) dan ancaman (Threats). Berikut adalah tabel pengamatan lingkungan yang penulis peroleh dari hasil melaksanakan praktik laut berkaitan dengan sistem pengabutan bahan bakar atau injector.

Tabel 1. Faktor Internal dan Eksternal

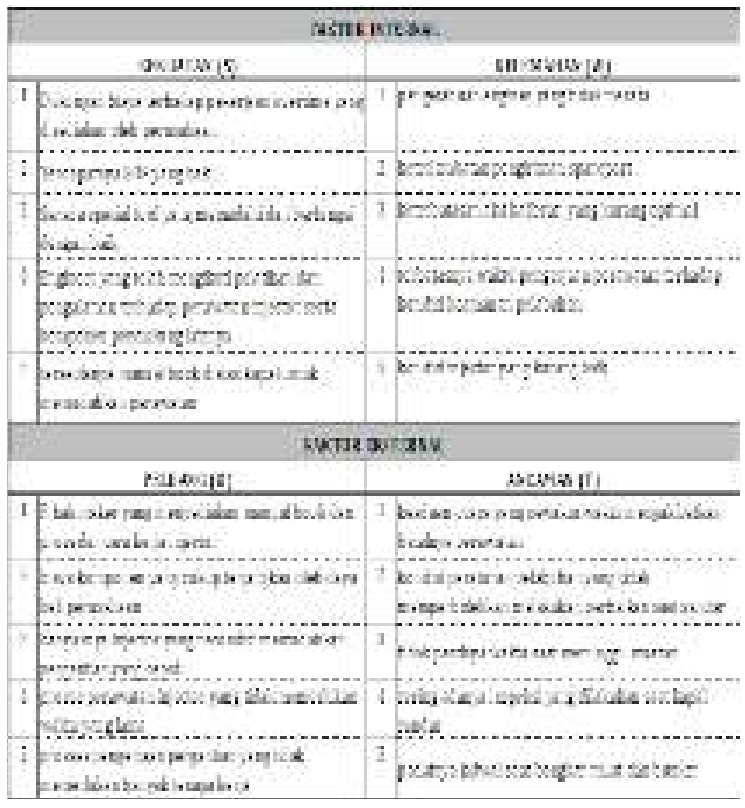

Setelah menentukan faktor-faktor internal dan eksternal langkah selanjutnya adalah memilih dan menetapkan penyebab kurang sempurnanya proses pengabutan bahan bakar melalui penilaian Bobot Faktor (BF), selanjutnya dilakukan penilaian terhadap faktor-faktor tersebut. Penilaian dilakukan melalui penentuan nilai faktor (NF) dan bobot faktor (BF) tiap faktor.

Pada tabel 1 berikut dilakukan penentuan Nilai Faktor masing-masing faktor serta ditentukan nilai Bobot Faktor dengan membandingkan nilai yang cenderung menjadi penyebab kurang sempurnanya proses pengabutan bahan bakar antara satu faktor dengan yang lainnya dengan rumus :

$$
B F=\frac{N U}{\sum N U} \times 100 \%
$$

Bobot Faktor akan dihasilkan dalam bentuk prosentase dari jumlah nilai urgencinya (NU) kesamping kanan dibagi dangan jumlah total hasil NU. Dari hasil tersebut di atas matrik ringkasan analisis faktor internal dan eksternal, dapat kita gambarkan dalam peta posisi faktor yang mempengaruhi kesempurnaan proses pembakaran pada sistem pengabut bahan bakar sebagai berikut:

Dimana nilai jumlah kekuatan $(\mathrm{S})=$ 2.11 dan nilai jumlah kelemahan $(\mathrm{W})=$ 5,20 maka selisihnya $(\mathrm{Y})=\mathrm{S}-\mathrm{W}$ dan hasilnya $\mathrm{Y}=-3.09$, sedangkan nilai jumlah peluang $(\mathrm{O})=5.19$ dan nilai jumlah ancaman $(\mathrm{T})=1,74$ maka hasil selisihnya $(\mathrm{X})=\mathrm{O}-\mathrm{T}$ dan hasilnya 3,45 sehingga titik tersebut berada di $(0.56 ;-1,05)$ atau di kwadran I yang terlihat pada gambar berikut:

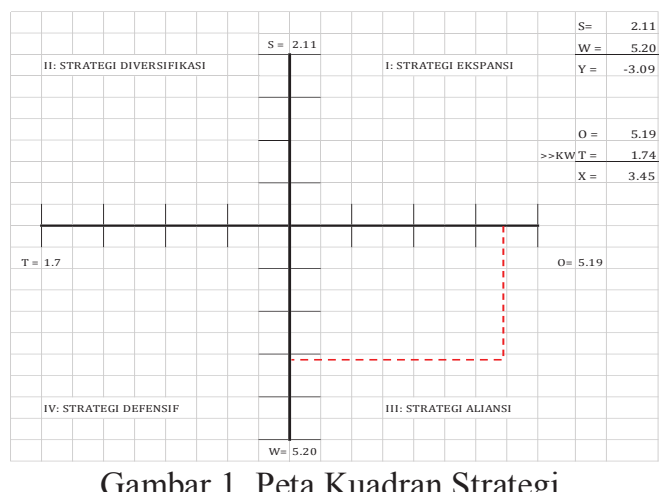

Gambar 1. Peta Kuadran Strategi 
Penentuan posisi hanya untuk mengarahkan permasalahan diselesaikan dengan strategi berdasarkan letak pada kuadran I, II, III, atau IV. Dari hasil perhitungan di atas diperoleh posisi berada pada kuadran III bahwa strategi yang digunakan adalah strategi Aliansi atau Weakness Opportunity (WO) strategi dimana strategi seperti ini memilih FKK (Faktor Kunci Keberhasilan) yang paling besar pada internal Weakness yaitu kondisi injector yang kurang baik.

\section{B. Pembahasan masalah}

1. Faktor yang mempengaruhi kondisi system pengabutan (Injector) yang kurang baik.

Injector menyemprotkan bahan bakar ke dalam silinder dalam bentuk kabut dan pada saat yang tepat yaitu pada saat akhir langkah kompresi, dengan tujuan agar bahan bakar terbakar dengan merata sehingga terjadi pembakaran yang sempuna di dalam silinder. Pada saat kapal sedang berlayar maka akan terjadi proses pembakaran di dalam silinder secara terus menerus ini akan mengakibatkan terjadi gesekan pada bagian-bagain di dalam injector tersebut, sehingga pada suatu saat terjadi penurunan kerja dan timbul kerusakan atau keausan pada alat pengabut. Hal ini disebabkan antara lain:

a. Lubang pengabut tersumbat atau terlalu lebar

Besarnya diameter dari lubang-lubang pengabut dibuat dengan ukuran tertentu. Apabila lubang pengabut terlalu kecil maka akan mudah tertutup dengan kotoran. Sedangkan apabila lubang pengabut terlalu besar maka bentuk kabut tidak akan halus.

b. Jarum pengabut tidak mau bergerak (melekat pada rumahnya) Jarum pada injector berfungsi untuk memberikan jarak (kerapatan antara jarum dengan rumahnya) terhadap bahan bakar yang masuk ke injector. Apabila jarum tidak mau bergerak maka jarum pengabut ini tidak lagi bekerja sebagai pengabut, karena minyak dari pompa bahan bakar yang dengan tekanan tinggi terlalu banyak mengalir melalui rongga antara jarum pengabut dengan rumahnya.

c. Pegas penekan jarum tidak bekerja dengan baik.

Pegas penekan berfungsi untuk menyetel kerapatan jarum terhadap mulut pengabut. Jika pada pegas yang sudah lemah karena elastisitasnya berkurang, maka penyetelan kerapatan jarum tidak dapat sempurna atau kurang pas sehingga tekanan bahan bakar yang dikabutkan menjadi tidak maksimal, hal ini disebabkan karena keausan dari pegas yang bekerja terlalu lama sehingga terjadi kelelahan bahan maka dari itu harus diganti dengan spring yang baru.

d. Tekanan pompa injeksi turun

Pompa injeksi adalah pompa bahan bakar tekanan tinggi dipergunakan untuk pengabutan tekan. Minyak mengalir ke dalam ruang isap dan silinder pompa di atas plunyer. Oleh gaya keatas pada torak pengantar plunyer turut bergerak. Setelah kepala plunyer menutup lubang isap dalam silinder pompa maka tekanan akan meningkat dan katup pengeluaran akan terbuka, selanjutnya bahan bakar di dalam pipa bahan bakar dan penyemprot juga mengalami penekanan. Bila plunyer sudah aus maka akan terjadi kebocoran. Dengan demikian minyak yang seharusnya masuk ke injector dengan tekanan yang tinggi tidak 
Ahmad Puji Nugroho, Darjono dan Okvita Wahyuni

dapat dikabutkan dengan baik. Jumlah bahan bakar yang akan dipompakan oleh bosch pump diatur oleh terbukanya helix. Kedudukan helix dapat diatur dengan fuel rack.

e. Terjadi kebocoran pada injector Pada injector apabila terjadi kabocoran maka pengabutan tidak akan sempurna. Maka untuk mengecek kebocoran dapat dilakukan dengan cara mengetes secara manual yaitu dengan cara memompakan alat pengetes yang sudah terpasang pipa pipa bahan bakarnya dengan rapat dan pompakan tuasnya sampai menuju titik normal pengabutan. Setelah mencapai titik normal tutup valve pada bahan bakar tunggu hingga beberapa saat dan apabila tekanan pada manometer menurun maka injector terdapat kebocoran. Apabila terdapat kebocoran maka lakukan penyukuran pada injector tersebut dan lakukan pengetesan kembali sampai tidak terdapat kebocoran.

2. Dampak yang ditimbulkan dari kurangnya perawatan injector pada motor induk.

a. Pengaruh terhadap pembakaran bahan bakar

Bila setiap bagian-bagian kecil bahan bakar setelah dikabutkan oleh injector maka akan memasuki ruang pembakaran dengan cepat akan terbakar dengan sempurna, maka lintasan tekan dan suhu dalam silinder sewaktu pembakaran dapat diketahui dari karakteristik penyemprotan dan kerja dari injector.

Ternyata memerlukan waktu untuk mengadakan reaksi kimia yang mengantar ke pelayanan dari campuran bahan bakar atau udara. Dalam campuran yang meliputi butir-butir bahan bakar yang disemprotkan karena akibat pengaruh dari tekanan dan suhu yang manguasai ruang pembakaran, akan mengakibatkan beberapa molekul yang dioksidasi sehingga membebaskan panas. Sebagai akibat dari suhu yang meningkat, maka kecepatan oksidasi akan meningkat dan demikian pula pembentukan panasnya. Bila pembentukan panas dalam campuran melebihi penyerahan panas ke dinding dari ruang pembakarannya, maka akan terbentuk suatu reaksi berantai dengan peningkatan tekanan dan suhu yang cepat sekali.

b. Pengaruh terhadap kinerja mesin induk

Pada mesin induk diesel, selama kelambatan penyalaan (ignition delay) telah dilampaui suatu jumlah derajat engkol yang relatif cukup besar. Untuk rendemen thermis motor, maka dikehendaki bahwa bahan bakar disemprotkan sepanjang derajat engkol yang terbatas dan pembakaran tidak berlangsung terlalu lama.

Sudut engkol sewaktu bahan bakar disembrotkan adalah sekitar $35^{\circ}-40^{\circ}$. Tidak optimalnya injector menyebabkan prosentase bahan bakar yang disemprotkan selama kelambatan penyalaan akan lebih besar, sehingga tekanan selama awal pembakaran juga akan lebih besar. Karena peningkatan tekanan yang cepat pada torak, maka seluruh penggerak motor bergetar dan getaran motor tersebut akan terdengar dari luar.

Dengan demikian akan berjalan dengan suara yang bergemuruh dan bila ada tekanan, karena suatu sebab perlambatan penyalaan menjadi terlalu besar, maka akan mengakibatkan kerusakan pada ring-ring piston dan bantalan 
(bearing) dari penggerak mesin.

c. Pengaruh kurang optimalnya injector terhadap kinerja motor diesel secara langsung antara lain:

1) Asap hitam

Bahan bakar yang telah berada dalam silinder sebagian tidak terbakar akibat dari pengabutan yang tidak sempurna (misalnya karena injector menetes) dan ikut keluar dengan gas pembakaran pada langkah buang, sehingga bahan bakar terbakar di dalam exhaust manifold. Jika bahan bakar terbakar di exhaust manifold maka asap yang keluar cerobong akan berwarna hitam.

2) Mesin susah hidup saat pertama kali start engine

Hal ini diakibatkan karena injector mengalami kebuntuan pada lubang penyemprotan ,hal itu disebabkan oleh kerak yang menutupi celah antara needle nozzle bahan bakar tidak bias mengabut bahkan keluar dengan sempurna dan pada saat start engine komposisi segitiga api yang menjadi faktor utama dalam pembentukan pembakaran engine tidak terpenuhi.

3) Suhu gas buang tinggi

Pada akhir langkah tekanan efektif dari pompa bahan bakar, maka seluruh bahan bakar tekanan tinggi akan kehilangan tekanan secara cepat, pada saat tersebut tidak semua bahan bakar dalam silinder terbakar sehingga akan diikuti dengan pembakaran tambahan pada bagian pertama dari langkah kerja. Bila pembakaran tambahan tersebut berjalan lama maka akan mengakibatkan panas yang tinggi.
3. Dampak yang ditimbulkan dari tidak meratanya tekanan kompresi pada tiap-tiap silinder pada mesin induk dalam waktu yang lama yaitu:

Terdapatnya beda tekanan pada tiap silinder yang mengakibatkan tidak meratanya daya tekan kompresi ke batang torak yang kemudian diteruskan ke putaran pada poros penggerak atau crankshaft sehingga menjadikan kelurusan tersebut menjadi terganggu atau bengkok. Dari bengkoknya shaft tersebut maka mesin induk mendapatkan gaya gesek yang lebih dan mengakibatkan putaran mesin menjadi berat, dan pada efek yang lama maka harus dilakukan perawatan untuk mengetahui kondisi yang seharusnya atau kondisi normal sesuai manual book yang tertera diatas kapal. Dari hasil analisa pengecekan harus mengukur kondisi cylinder liner, piston ring, main bearing clearance, crank pin bearing clearance, crank web deflection dan piston ring gap. Kegiatan pengukuran tersebut dilakukan untuk menjaga dan mengetahui kondisi pada crankshaft dan piston serta cylinder liner agar mesin induk dapat bekerja secara optimal.

4. Upaya perawatan yang sesuai pada sistem pengabutan bahan bakar pada motor induk

Kondisi pembakaran motor diesel sangat tergantung dari kondisi pengabut bahan bakar, maka dari itu perawatan sistem pengabut bahan bakar harus dilaksanakan dengan baik, untuk itu diperlukan suatu perencanaan perawatan yang tepat agar tidak menggangu pengoperasian kapal, langkah-langkah dalam perawatan pengabut bahan bakar adalah sebagai berikut :

a. Pemeriksaan dan pengetesan injector

Pemeriksaan dan pengetesan 
Ahmad Puji Nugroho, Darjono dan Okvita Wahyuni

injector harus dilakukan sesuai dengan instruction manual book agar hasil yang dicapai dapat maksimal. Hasil dari pemeriksaan dan pengetesan injector dari masing-masing silinder harus dicatat sehingga dapat dijadikan referensi dan pedoman untuk perawatan berikutnya

Pemeriksaan dan pengetesan tersebut adalah sebagai berikut : Pengetesan injector dilakukan tiap jam kerja atau terpakai 500-1000 jam putaran motor. Sebelum mengadakan pengetesan periksa terlebih dahulu nozzle dan lubang injeksi jika ada kerak karbon/arang yang menutupi, maka harus dibersihkan terlebih dahulu.

- Pengetesan injector tersebut meliputi :

1) Injection test (tes
penyemprotan) perlahan dengan menggunakan injector tester. Mengukur tekanan pada saat injector mulai menyemprot. Sesuai dengan buku petunjuk di kapal taruna praktek yaitu YANMAR DIESEL ENGINE INSTRUCTION $B O O K$ bahwa pengaturan tekanan pada saat pembukaan katup injector adalah 320 $\mathrm{kg} / \mathrm{cm} 2$.

2) Atomization test (tes pengabutan)

Ketika tekanan bahan bakar menjadi cukup tinggi maka akan membuka katup sehingga bahan bakar akan mengabut. Pengabutan bahan bakar harus menyebar dengan teratur dan tidak boleh menetes. Pengabutan dipengaruhi oleh pergerakan dari jarum pengabut dan ketepatan dari pengaturan tekanan, jika lubang mulut pengabut ada yang tersumbat maka pengabutan akan kurang, jika kondisi jarum pengabut dan rumahnya tidak baik maka injector akan menetes, apabila terjadi demikian maka injector harus diatur kembali atau dengan mengganti nozzle.

3) Pressure resistance test (tes penurunan tekanan)

Pengetesan yang dilakukan untuk mengetahui waktu penurunan tekanan dari tekanan yang ditentukan menuju tekanan tertentu harus sesuai dengan yang dikehendaki.. Sesuai instruction manual book waktu untuk penurunan dari 320 $\mathrm{kg} / \mathrm{cm} 2$ menuju $220 \mathrm{~kg} / \mathrm{cm} 2$ adalah 30-90 detik.

5. Upaya yang dilakukan untuk kerusakan pada jangka panjang akibat dari tidak samanya tekanan kompresi pada tiap silinder.

a. Pemeliharaan terhadap viscosi meter

Viscosi meter ini digunakan untuk mengatur viscosity bahan bakar yang dipanasi menggunakan uap atau steam yang dibuka atau ditutup sesuai dengan peraturan yang diatur dengan thermostat.

Uap-uap yang mengandung udara, air dan kotoran yang berada di dalam pipa steam harus dijaga kondisinya sehingga diperlukan adanya perawatan sebagai berikut:

1) Selalu mencerat uap pada pipa steam untuk menghilangkan atau mengeluarkan air yang ada didalamnya sehingga uap yang ada di dalam pipa menjadi bersih dan tidak mengandung banyak air dan panas yang dihasilkan menjadi maksimal.

2) Selalu mengecek atau memantau viscositas bahan bakar dengan mencatat hasil pengecekan agar selalu dalam 
kondisi yang sesuai dan jika tidak sesuai maka agar dapat ditangani sedini mungkin sehingga kualitas bahan bakar selalu terjaga.

3) Selalu menjaga kondisi pipa steam agar terhindar dari kebocoran akibat dari korosi dan selalu membungkus pipa-pipa steam sebagai prosedur keselamatan dalam bekerja.

b. Melakukan pengukuran Main engine crank web deflection

Prosedur pengambilan crank web deflection pada mesin induk :

1) Cek kandungan gas di dalam mesin induk dengan gas detector dengan kandungan oksigen $21 \%$;

2) Atur turning gear pada posisi remote control;

3) Atur deflection gauge letakan pada posisi crank shaft;

4) Dan tempatkan deflection gauge pada posisi kiri bawah;

5) Jalankan turning gear menggunakan remote untuk memutarkan shaft.

\section{KESIMPULAN}

\section{A. Simpulan}

Berdasarkan uraian-uraian pada bab sebelumnya, maka penulis mengambil beberapa kesimpulan dengan harapan dapat memberikan pedoman atau penyelesaian tentang masalah yang sama kepada para pembaca, yaitu sebagai berikut :

1. Pengaruh kesempurnaan pembakaran pada motor induk bahan bakar antara lain : Daya kerja dari motor induk menjadi menurun sehingga konsumsi bahan bakar menjadi boros akibat dari kondisi injector yang tidak baik.

2. Pengaruh kurang optimalnya kerja injector dalam mengabutkan bahan bakar dalam waktu yang berkala antara lain : Akibat dari tidak samanya tekanan kompresi pada tiap-tiap silinder maka pada posisi crank shaft akan bengkok karena mendapat tekanan yang berbeda pada tiap sisi silinder.

3. Upaya mengoptimalkan kerja injector antara lain: Menjaga system pengabutan bahan bakar agar pembakaran pada motor induk menjadi optimal dengan melakukan perawatan sesuai instruksi manual book di kapal.

\section{B. Saran}

Dari kesimpulan di atas maka penulis dapat memberikan saran mengenai permasalahan yang dibahas dalam bab sebelumnya, yang mana saran tersebut semoga dapat dijadikan pedoman dalam menyelesaikan masalah yang terjadi di atas kapal, antara lain sebagai berikut :

1) Perlunya meningkatkan perawatan injector untuk mencegah tersumbatnya lubang pengabut dari kerak dan menjaga kualitas bahan bakar agar terjadi pengabutan yang sempurna.

2) Perlunya perawatan dan perbaikan injector yang teratur dan terencana serta jika ditemukan kelaian dan gangguan pada injektor harus diatasi sedini mungkin sehingga mesin induk dapat bekerja dengan optimal sebagai mesin penggerak utama.

3) Perlunya perawatan dengan memperhatikan kondisi jam kerja permesian dan pengecekan yang dilakukan dari dampak yang ditimbulkan baik dalam jangka waktu yang singkat dan dampak jangka panjang dari tidak sempurnanya pembakaran bahan bakar pada mesin induk. 
Ahmad Puji Nugroho, Darjono dan Okvita Wahyuni

\section{DAFTAR PUSTAKA}

Burghardt dan Kingsley. 1983. Marine Diesels. New York : United States Merchant Marine Academy, Kings Point

Fatimah. 2016. Teknik Analisis SWOT. Jakarta : PT. Triasko Madra

Indrawan dan Yuniawati. 2014. Teknik Pengumpulan Data. Bandung : PT. Alfabeta

Kartono, Katini. 1996. Pengantar Metodologi Riset Sosial. Bandung : PT. Mandar Maju

Maleev, L dan DR.A.M. 1996. Operasi dan Pemeliharaan Mesin Diesel. Jakarta : PT. Pradnya Paramita

Setiawan. 2016. Kegiatan Menghimpun Informasi. Yogyakarta : Quadrant

Sugiyono. 2009. Metodologi Penelitian dan Teknik Penyusunan Skripsi. Bandung : CV Alfabeta

Tim Penyusun PIP Semarang. Motor Diesel Penggerak Utama.

Van Maanen, P. 1999. Motor Diesel Kapal, jilid 1. Jakarta : PT. Triasko Madra

Harrington, L. Roy. 1998. Marine Engineering. Jakarta : Djangkar 